include extensive research in industry, in the universities and in Government bureaux to develop new products and processes, the improvement of educational standards and the technique of production and distribution and of transport, building and public health.

The expansion of expenditure on public welfare, including old-age pensions and family allowances, is suggested, and the importance for international cooperation of pursuing internal policies designed to promote active employment as well as for the development of backward countries and for implementing ways and means to open outlets for foreign investment, promote world trade and the world-wide use of productive resources is recognized. With regard to the war period, a policy of high income and excess profits tax with a broadening of the individual incometax base and steeply graded surtax-rates is advocated, as well as the part-payment of wages and salaries in defence bonds and a sharp increase in excise taxes on commodities competing with the war programme. In the post-war period a policy of retaining the progressive tax structure and broadened tax base with a major emphasis on the individual income-tax and less reliance on the corporate income-tax is suggested, together with a sharp reduction in defence consumption taxes and adequate plans by private enterprise for investment in manufacturing plant and equipment, railroads, public utilities and housing.

\section{The Third Earl of Rosse and his Telescopes}

Mr. M. A. Ellison has described (J. Brit. Astro. Assoc., 52, Sept. 8, 1942) the celebrated experiments of William Parsons between 1827 and 1845 for the improvement of reflecting telescopes. The earlier workers in speculum metal had jealously guarded their secrets of grinding and polishing, and each step in the process had to be established anew by experimenters. The earliest researches of Parsons were undertaken to determine the composition of speculum metal, which should possess the qualities of whiteness, high reflectivity, and resistance to tarnish. It was found that the conditions were best realized in an alloy of four atoms of copper to one of tin, and specula differing to a slight degree from this proportion of the alloys were found to dim rapidly, though they were quite brilliant when polished. Unfortunately, this alloy was liable to shiver at the slightest blow or sudden temperature changes, and attempts to cast it in disks more than about a foot in diameter were abandoned.

A description is given of the different telescopesthe 3 -ft., the 6 -ft., and the 18 -in. reflectors-and also of their mountings. There was a general impression that the 6 -ft. reflector had an altazimuth mounting. Actually, the movements of this telescope were equatorial, but they were limited to one half-hour on each side of the meridian. It is interesting to notice that $\gamma_{2}$ Andromedæ was used as evidence of its defining power. Robinson records that he saw the system distinctly, as two neatly separated stars, under a power of 828 . The separation at this time (1845) was about $0 \cdot 5^{\prime \prime}$. The paper concludes with a list of assistants at Birr Castle Observatory and a short account of their work.

\section{Indian Precious Stones}

The Geological Survey of India has recently commenced the publication of a series of Bulletins of Economic Minerals as a war-time measure to direct attention to India's mineral resources. Those issued in 1941 deal with chromite, strontium minerals, phosphates and clay, and several others are in preparation. No. 6 (1942), "Indian Precious Stones", by Dr. L. A. N. Iyer, is a useful pamphlet of fifty-four pages, with two plates illustrating the mining of ruby at Mogok in Burma. It rather gives the impression of a hasty compilation from scattered sources of information; but some additional matter is given relating to the Mogok "stone tract", where the author was engaged in the production of the Geological Survey maps. There, in addition to ruby, a considerable variety of minerals of gem quality has been found. Apart from these, and the sapphire of Kashmir and the many gemstones of Ceylon, there are really few occurrences of importance in India proper, except for semi-precious stones such as agate and almandine garnet.

At one time, however, India was the only known source of diamond, and many of the famous stones found centuries ago are of Indian origin. (One of these, known as "The Moon of the Mountains", was sold by auction in London in August 1942 for $£ 5,200$.) At the present time the production is very small, averaging for the years 1929-33 less than 1,500 carats ( 300 grams) and valued at 74,040 rupees $(£ 5,555)$, the bulk of this coming from Panna State. It would be interesting to know how many persons, working by primitive methods in small and scattered pits, were engaged in producing this handful ( $\frac{2}{3} \mathrm{lb}$.) of small diamonds. They would be of no use in the trade as industrial diamonds. India is actually a large importer of diamonds for jewellery purposes. At one time India. was also the sole producer of corundum (of which ruby and sapphire are colour varieties of gem quality) for abrasive purposes, and in fact the name corundum is of Indian origin, but the present output is again very small.

\section{Refrigeration of Fish in Australia}

AN account of the application of refrigeration to the Australian fishery industry has been published by the Council for Scientific and Industrial Research (Commonwealth of Australia: Division of Food Preservation and Transport. Circular No. 4.-P, Melbourne 1, 1942). This is written in non-technical language and has been prepared to serve as a guide to the fish industry on the basic refrigeration requirements. As the result of a survey of the important fishing centres along the south coast of New South Wales and some centres in Victoria and Tasmania, it was found that it was possible to catch in eastern Australian waters considerable supplies of fish suitable for an important canning industry as well as for a substantial trade in fresh fish. Serious difficulties must, however, be overcome before any great expansion can take place. These notes are issued as a guide to future development based on the necessity for preserving fish by refrigeration to meet the requirements of a large and stable industry.

\section{Tin Economy in Cable Jointing}

A NEw type of wipe or fillet joint is described by J. T. Lowe (Bell Lab. Rec., 20, No. 11, July 1942) which makes it possible to meet the essential requirements for a wiped joint using far less solder without the necessity for a new wiping technique. Essentially, the new method consists of carefully beating in the cable sleeve ends to the proper shape to facilitate formation of a satisfactory fillet of solder and to obviate rounding out the sleeve ends with solder. 